\title{
Human impact during the Bronze Age on the vegetation at Lago Lucone (northern Italy)
}

Received: 6 October 2004 / Accepted: 30 September 2005 / Published online: 14 December 2005

(C) Springer-Verlag 2005

\begin{abstract}
Lake-sediment records were used to reconstruct human impact on the landscape around Lago Lucone $\left(45^{\circ} 33^{\prime} \mathrm{N}, 10^{\circ} 29^{\prime} \mathrm{E}, 249 \mathrm{~m}\right.$ a.s.l. $)$, a former lake in the western amphitheatre system of the Lago di Garda. Presence of prehistoric human populations is attested by pile-dwelling settlements from the Early-Middle Bronze Age, with one settlement at a distance of only $100 \mathrm{~m}$ from the coring site. Pollen, plant-macrofossil and microscopic charcoal analyses were applied to a $250 \mathrm{~cm}$ sediment core with four dates providing the time control. A mixed oak forest that was important during the Early-Middle Holocene was cleared and replaced by open vegetation during the Bronze Age ( 2000-1100 B.C.) when open lands were estimated to have covered more than $60 \%$ of the total relevant pollen-source area. During a phase of high human impact, independent climatic proxies suggest warm and dry climatic conditions. Later, ca. 1100 B.C., palaeobotanical evidence indicates a sharp decrease in human pressure in the Lago Lucone area. The comparison with other sedimentary palaeocultural records shows that the period 1300-1100 B.C. was characterised by general declines of agricultural activities both south and north of the Alps. These declines have been previously attributed to a change towards wetter and colder climatic conditions in and around the Alps. However, the decline in human impact around Lago Lucone cannot be exclusively attributed to climatic variation. Therefore other
\end{abstract}

V. Valsecchi $(\bowtie) \cdot$ W. Tinner · W. Finsinger · B. Ammann Institute of Plant Sciences, University of Bern, Altenbergrain,

21, CH-3013 Bern, Switzerland

e-mail: verushka.valsecchi@unimi.it

Tel.: +31-30-253-2765

Fax: +31-30-253-5096

V. Valsecchi

Department of Earth Science "Ardito Desio", University of

Milan, Via Mangiagalli,

34 I-20133 Milano, Italy

W. Finsinger

Department of Plant Biology, University of Rome

"La Sapienza",

Piazzale Aldo Moro 5,

I-00185 Roma, Italy forcing factors independent of climatic changes, such as cultural crises or changes in spatial organisation of the habitats, cannot be ruled out under the present state of knowledge.

Keywords Pollen analysis - Plant macrofossil analysis . Bronze Age · Human impact - Climatic changes . Northern Italy

\section{Introduction}

Several archaeological findings show the presence of Neolithic settlements in the amphitheatre moraine system of the Lago di Garda, northern Italy. During the Early and Middle Bronze Age (ca. 2200-1300 B.C.), the number of settlements increased, as attested by the spread of pile dwellings near lakes or former lakes present in the moraine system of the Garda area and by settlements at high altitudes (Cremaschi 1991-1992). Compared with the Neolithic, human management of the landscape became more intense, with more extensive cultivation and animal husbandry, accompanied by a development towards more complex societies (Castelletti et al. 2001). After this rich settlement phase a general decrease in evidence from settlements is found in the Garda area starting at the transition between the Middle and Late Bronze Age (ca. 1300 B.c.).

In spite of the greater number of Bronze-Age dwellings in north-eastern Italy, only few palynological studies have been carried out in prehistoric pile-dwelling areas. On-site records and records from very close to settlements were studied in the Lago di Garda area (Lago di Ledro, Dalla Fior 1940; Lago di Castellaro, Bertoldi 1968; Fiavè mire, Dalla Fior 1932) and in the Po Plain (Terramara di Santa Rosa di Poviglio, Ravazzi et al. 2004; Tabina di Magreta, Bertolani Marchetti et al. 1989).

However in northern Italy and the adjacent Ticino region several palynological records not placed in an archaeological context (off-site records) provide accurate chronological positions for particular events (Schneider and Tobolski 1985; Wick 1996b; Tinner et al. 1999; Gobet et al. 
2000, 2003; Finsinger 2001). Although in all settings human impact is visible, different extents of deforestation are observed in different records.

In order to understand the degree to which land was used by prehistoric populations, it is important to assess how changes in land use are registered in pollen records. Therefore comparisons should be attempted among the available palynological records inside prehistoric settlements, in their vicinity and remote from them. Lago Lucone was selected because Early to Middle Bronze Age settlements occurred near the lakeshores (Guerreschi 1980-1981; Bocchio 1985-1988). This site is therefore suitable to test the extent to which the landscape changed and how this change was registered in pollen and plant-macrofossil records. Moreover, because the coring location is close to the settlement, the signal from human impact in the palaeoecological record is enhanced. The archaeological record of Lago Lucone, parallel to the settlement phase in the Garda area, also shows the disappearance of the pile dwelling at the end of the Middle Bronze Age. However, a few artefacts from the Late and Final Bronze Age were found at Lago di Lucone (Guerreschi 1980-1981).

In this study we establish whether the decrease in landuse intensity as suggested by archaeological evidence from the transition Middle to Late Bronze Age is reflected in the palaeobotanical records of Lago Lucone. In addition, the comparison of our records with independent climatic proxies enables us to discuss potential correspondence between human occupation phases and variations in climate.

\section{Study area (geographical, vegetation, climatic and archaeological setting)}

Lago Lucone $\left(45^{\circ} 33^{\prime} \mathrm{N}, 10^{\circ} 29^{\prime} \mathrm{E}, 249 \mathrm{~m}\right.$ a.s.l.) is located in the western part of the amphitheatre system of Lago di Garda (Polpenazze-Brescia) and is nowadays a marshy area with Alnus glutinosa stands (Fig. 1). The lake was drained in A.D. 1459 in order to increase the cultivation area (Stegagno 1907). The basin receives its water from the major inlet, which flows from springs at the foothills of the Monte Soffiano (363 m a.s.l.). The outlet, Rio Seriola, is artificial and flows into the Rio Borgognini, which in turn enters the Lago di Garda (50 $\mathrm{m}$ a.s.l.). Before reclamation, the natural outlet passed between Monte San Pietro and Monte Basia, respectively 295 and 302 m a.s.l. (Stegagno 1907). Moraines of the Riss Stadial and other Quaternary sediments surround the former lake (Venzo 1957). Near the northern side of the basin, Tertiary carbonate rocks are present.

A mixed oak forest (Quercus robur, Q. pubescens and Ostrya carpinifolia) covers the moraines, and Quercus cerris and Castanea sativa grow on acidic soils. The mild climatic regime accounts for the presence of Mediterranean plants like Cupressus sempervirens, Olea europaea, and Laurus nobilis in the forest (Marchesoni 1958).

The study area is situated in the transitional climatic zones Cfa and Cfb of Köppen (Pinna 1977). The nearby

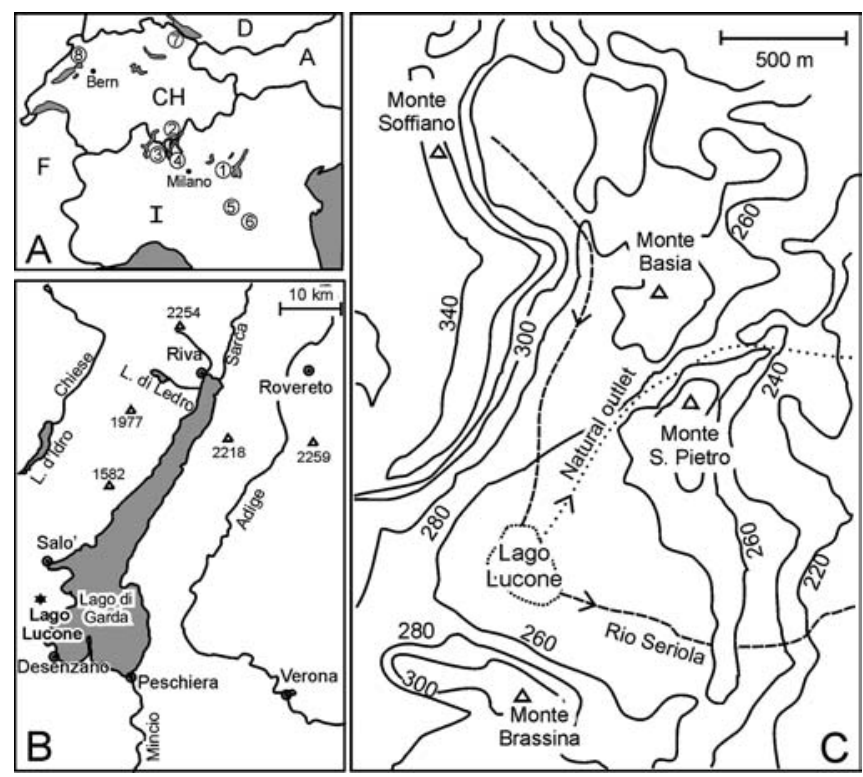

Fig. 1 Map of the study region. A sites mentioned in the text: 1 former Lago Lucone (this study); 2 Lago di Origlio and Lago di Muzzano (Tinner et al. 1999; Gobet et al. 2000); 3 Lago di Ganna (Schneider and Tobolski 1985); 4 Lago di Annone and Lago di Segrino (Wick 1996b; Gobet et al. 2000); 5 Terramara Santa Rosa di Poviglio (Ravazzi et al. 2004); 6 Tabina di Magreta (Bertolani Marchetti et al. 1989); 7 Nussbaumersee (Ammann 1977); 8 Twann (Haas and Hadorn 1998). B location of the Lago di Garda area. C location of the former Lago Lucone

climatic station of Saló (Fig. 1) shows the present day annual precipitation to be $1,000 \mathrm{~mm}$, with maxima in spring and autumn. The annual, July and January mean temperatures are 13, 24 and $2^{\circ} \mathrm{C}$ respectively (Ufficio idrografico e mareografico di Parma-Bacino del Po 1962-1991).

The archaeological findings at the Lago Lucone are distributed in five different areas (Fig. 2; Baioni and Bocchio 2004). Neolithic artefacts (Vasi a Bocca Quadrata) have been found in area $\mathrm{C}$ (Fig. 2), while other investigated areas provided only Bronze Age findings. At Lucone, two pile dwellings were excavated in areas $A$ and $D$, where lithic and bronze assemblages were correlated to the Early and Middle Bronze Age (Guerreschi 1980-1981; Bocchio 1985-1988). A more accurate dating is provided by the dendrochronological investigation carried out on 50 Quercus sp. posts which suggests that the settlement in zone D was restricted to the Early Bronze Age from $2166 \pm 10$ to $1987 \pm 10$ в.C. (Martinelli 1996). Plant macrofossil analysis on material found during the excavation in areas A and D highlighted cultivation of Triticum sp., Panicum miliaceum, and Hordeum sp. (Guerreschi 1980-1981; Bocchio

Table 1 Chronology of the Bronze Age in Garda area ${ }^{a}$

\begin{tabular}{ll}
\hline Age B.C & Periods of the Bronze Age \\
\hline $1150-800$ & Final \\
$1300-1150$ & Late \\
$1600-1300$ & Middle \\
$2200-1600$ & Early \\
\hline
\end{tabular}

${ }^{\text {a }}$ Source de Marinis (1999) 


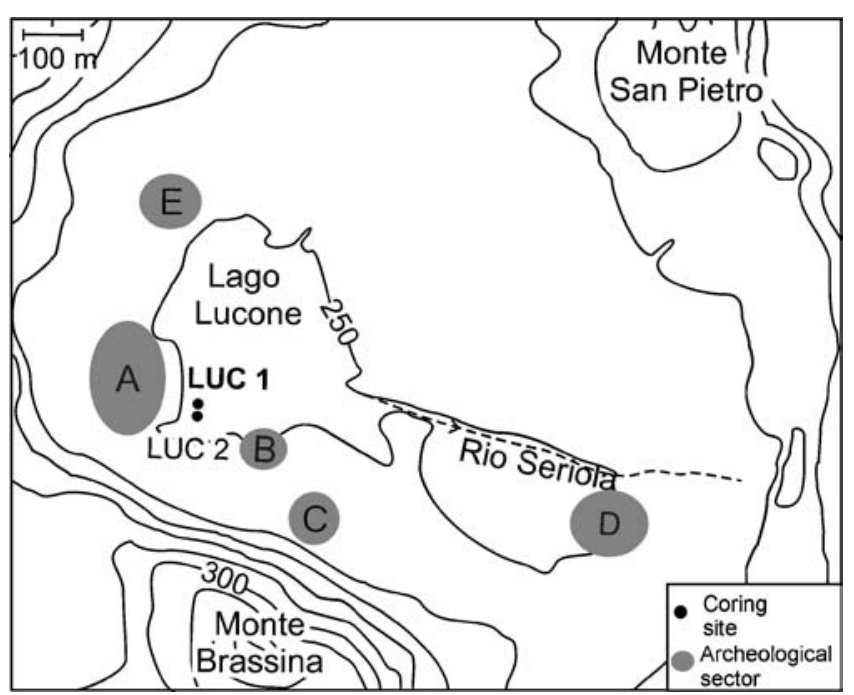

Fig. 2 Map showing archaeological sectors (grey areas) and coring sites (black dots). The archaeological sectors can be grouped as follows: C-Neolithic artefacts, $\mathbf{A}$ and $\mathbf{D}$-Early-Middle Bronze Age settlements, $\mathbf{B}$ and $\mathbf{E}-$ Bronze Age findings

1985-1988). Table 1 shows the chronological scheme for north-eastern Italy during the Bronze Age (de Marinis 1999) used in this paper.

\section{Materials and methods}

Fieldwork

A Streif piston corer of $8 \mathrm{~cm}$ diameter (Merkt and Streif 1970) was used to take parallel cores $100 \mathrm{~m}$ from the dwelling area A (Fig. 2). The two cores (LUC-1 and LUC-2 of 7 and $4 \mathrm{~m}$ length, respectively) were described following Faegri and Iversen (1989) and using Munsell charts (1954) for the sediment colour. Since sedimentological features of the two cores were comparable, only core LUC-1 was analysed because of its greater length. In both cores the first $90 \mathrm{~cm}$ were not recovered because of ploughing disturbance.

Pollen and microscopic charcoal analysis

Samples for pollen analysis were taken between 90 and $250 \mathrm{~cm}$ with sampling at higher temporal resolution between 180 and $140 \mathrm{~cm}(\sim 2300$ to 250 B.C.); in total 33 samples were analysed. Pollen samples of $1 \mathrm{~cm}^{3}$ were prepared by standard physical $(500 \mu \mathrm{m}$ sieving and decantation) and chemical ( $\mathrm{HCl}, \mathrm{KOH}, \mathrm{HF}$ and acetolysis) methods. Lycopodium tablets were added for estimation of pollen concentration (Stockmarr 1971). Pollen grains and spores were counted at magnifications of $\times 400$ and $\times 1000$ and identified with keys (Punt et al. 1976-1996; Moore et al. 1991), pollen atlases (Reille 1992-1998) and the reference collection at the Institute of Plant Sciences in Bern. At least 400 pollen grains per sample, excluding aquatic plants and ferns, were counted. The results are presented as TILIA pollen percentage diagrams (Grimm 1993). Charcoal particles longer than $10 \mathrm{~mm}$ were identified in the pollen slides with a light microscope at $\times 250$ magnification. Charcoal was identified as black, completely opaque, angular fragments and at least 200 objects were counted for each sample (Tinner and $\mathrm{Hu}$ 2003; Finsinger and Tinner 2005). Rarefaction analysis using the program RAREPOLL (Birks and Line 1992) was carried out using the raw count to estimate the palynological richness, the lowest pollen count (410 grains) was used as the reference sum.

Plant-macrofossil analysis and dating

For plant macrofossils, 110 contiguous sub samples were taken between 140 and $250 \mathrm{~cm}$ sediment depth. These were wet sieved (mesh widths of 200 and $100 \mu \mathrm{m}$ ) after measurement of their volume by water displacement. Macrofossils greater than $200 \mu \mathrm{m}$ were analysed with a stereomicroscope at 10-40× magnification and identified using the seed reference collection of the Institute of Plant Sciences of the University of Bern and atlases (Katz et al. 1965; Schoch et al. 1988). Macrofossil concentrations are referred to a volume of $50 \mathrm{~cm}^{3}$ sediment. Macroscopic remains of terrestrial plants were selected from four sediment levels and dated by accelerator mass spectrometry (AMS) at the Poznań Radiocarbon Laboratory. The resulting radiocarbon dates were converted to calendar year B.P. (cal B.P.) with the program CALIB rev 4.3 method A (Stuiver and Reimer 1993; Stuiver et al. 1998. Linear interpolation between the means of calibrated dates was used to estimate the depth-age relationship (Fig. 3).

\section{Loss on ignition (LOI)}

Samples of $1 \mathrm{~cm}^{3}$ of wet sediment were taken between 90 and $250 \mathrm{~cm}$ depth and dried at $105^{\circ} \mathrm{C}$ for $12 \mathrm{~h}$. Then the samples were heated for $4 \mathrm{~h}$ at $550^{\circ} \mathrm{C}$ and for $2 \mathrm{~h}$ at $950^{\circ} \mathrm{C}$. The weight loss, which represents the content of organic matter and carbonate of the sediment (Heiri et al. 2001), was measured by weighting the samples before and after heating. The LOI of the sediment was calculated as the percentage dry-weight loss after ignition.

\section{Characterisation of the open land}

Pollen percentages of herbaceous indicator species were used to characterise the use of the non-forested area from the Copper Age until Modern Times. The categories here considered were field, fallow and ruderal communities, pastures, mowing, wet meadows, dry meadows and finally the occurrence of the species as an element of the natural communities of the Garda area. Herb pollen types were assigned to these categories of land use according to previous studies as follows: (i) the anthropogenic indicator-species approach of Behre (1981), (ii) the indicator values of 

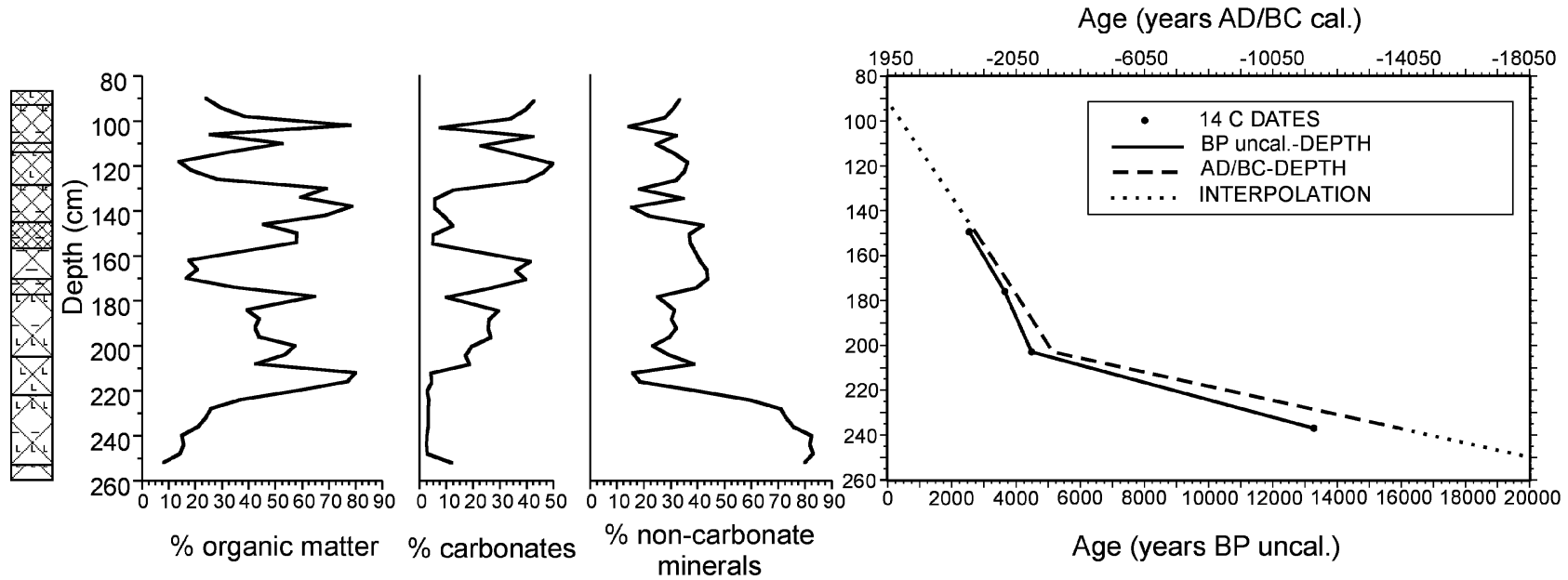

Fig. 3 Lithostratigraphy, loss-on-ignition curves and depth-age model for core LUC-1. For lithostratigraphic legend see Fig. 4

pollen types for grazing, mowing and wetness of Birks (1990) on a 9-point scale (for our estimations only the pollen types with values of 7,8 , and 9 were used), (iii) the indicator values for mowing and grazing of Gaillard et al. (1992) on a 5-point scale (only pollen types with a score of 4 or 5 were used), (iv) the index for humidity (F) of Ellenberg et al. (1992) and (v) the ecological indications of Pignatti (1982). Several NAP-types were not considered as anthropogenic indicators because the pollen was derived from plant species that either occur in present-day natural communities (i.e. Centaurea nigra t.) or which are related to different land-use (i.e. Artemisia). Percentages of the indicator species were then grouped according to land-use category by summing pollen percentages (Table 5 and Fig. 6).

Estimation of the landscape openness within the relevant-source-area

The quantitative estimation of the landscape openness (e.g. percentage of open land, forested land, etc.) is possible once the "relevant source area" (RSA) of the study site is known (Broström et al. 1998; Gaillard et al. 1998; Sugita et al. 1999). The RSA of pollen is the area within which local differences in plant abundance are recorded as variance in pollen assemblages. It can be considered as the area beyond which the correlation between pollen loading and distanceweighted plant abundance does not improve (Sugita 1994).

Care should be taken when estimating the percentage of open land represented by non-arboreal pollen (NAP), for this procedure gives only a non-linear approximation (Sugita et al. 1999). Moreover, in order to estimate quantitatively the landscape openness from pollen data it is necessary to know the background pollen values and pollen production (Sugita et al. 1999). Then the vegetation composition of the RSA is obtained from a pollen assemblage by using the inverse forms of the Extended $R$-value model. The model described by Sugita et al. (1999) cannot be fully applied here because the background pollen, pollen production and fall speed of pollen in the study area were not estimated. Although the use of NAP percentage is tentative, because landscape openness and NAP percentages are not linearly related, we decided to use this value in order to have a first estimate of the percentage of open land.

Since at Lago Lucone the Bronze Age settlements were located on the $250 \mathrm{~m}$ contour, we inferred a palaeo-lake area of $\sim 18$ ha and estimated the radius as about $1000 \mathrm{~m}$ (for small lakes 0.5-20 ha) for the RSA, following Broström et al. (1998). Subsequently, the landscape openness within the RSA was estimated following the model-based relationships between NAP percentages versus percentage cover of open land (Fig. 4b in Sugita et al. 1999; results in Table 4).

\section{Results and interpretation}

Lithostratigraphy and loss-on-ignition

At the base the sediment of the core LUC-1 consists of silty clay with increasing organic matter followed by a dark silty gyttja between 180 and $158 \mathrm{~cm}$. Then a detritus gyttja 158$144 \mathrm{~cm}$ is overlain by an alternation of gyttja and clay gyttja up to $90 \mathrm{~cm}$ depth (Table 2 and Fig. 3). The sediment above $90 \mathrm{~cm}$ was not cored as ploughing had disturbed it. These results are borne out by the loss-on-ignition (LOI) analysis. From the bottom to $215 \mathrm{~cm}$ depth percentages of non-carbonate minerals are high in the sediment. This level is followed by a sharp change highlighted by a sharp increase in organic matter and carbonate (Fig. 3).

\section{Depth-age model}

The earliest date (Table 3) at a depth of $237 \mathrm{~cm}$ has a mean age of 15960 cal B.P. Since no significant change in the sediment composition is apparent below the last level dated a constant accumulation rate would lead to an age at the bottom of ca. $20000 \mathrm{cal}$ B.P. $(250 \mathrm{~cm})$. The most recent date at $149 \mathrm{~cm}$ has a mean age of $2735 \mathrm{cal}$ B.P. Changes in sedimentation rate cannot be excluded for the top section of the core. However, despite the few dates available, a 
Table 2 Description of the Lago Lucone sediments (core LUC-1)

\begin{tabular}{lll}
\hline Depth $(\mathrm{cm})$ & Description & Colour \\
\hline $66-77$ & (Clay) gyttja & 10 YR 2/2 \\
$77-93$ & (Silty clay) gyttja & $2.5 \mathrm{Y} \mathrm{4/2}$ \\
$93-111$ & (Silty clay) gyttja & $10 \mathrm{YR} \mathrm{4/3}$ \\
$111-114$ & (Clay) gyttja & 10 YR 2/2 \\
$114-130$ & (Silty clay) gyttja & 10 YR 4/3 \\
$130-144$ & (Clay) gyttja & 5 YR 2/2 \\
$144-158$ & Silty detritus gyttja & 10 YR 2/2 \\
$158-171$ & Silty gyttja & 5 Y 3/2 \\
$171-179$ & Silty clay gyttja & 10 YR 2/2 \\
$179-207$ & Clay silty gyttja & 5 Y 4/2 \\
$207-223$ & Clay gyttja & 10 YR 2/2 \\
$223-253$ & Clay silty gyttja & 5 YR 4/2 \\
$253-256$ & Silty clay gyttja & 5 YR 5/1 \\
\hline
\end{tabular}

tentative depth-age model was constructed assuming a constant sedimentation rate to the top of the sediment cored; for the $90 \mathrm{~cm}$ depth the estimated date was A.D. 1950.

As shown by the LOI results, non-carbonate minerals mainly form the deposits at the bottom of the core, whereas an increase of organic matter occurs at around $215 \mathrm{~cm}$ (ca. 7000 в.C.). It is likely that this sedimentary change was connected with the decrease of the accumulation rate visible in the depth-age model at $\sim 205 \mathrm{~cm}$. Later, in the time frame of our interest (i.e. from $\sim 3000$ B.C.), the sedimentation rate was fairly constant.

\section{Vegetation history}

Pollen and plant-macrofossil diagrams were subdivided into five and four zones respectively (Figs. 4 and 5). The visual zonation of the diagrams is based on changes in pollen percentages (LPAZ), and plant macrofossil concentrations (MZ).

\section{LPAZ Luc-A and MZ Luc-A (250-225 cm), ca. 20000?-12100 cal B.P.}

At the base of the zone, herb pollen types were dominant, particularly Artemisia and Poaceae. Among the arboreal pollen, Pinus sylvestris type (from $20 \%$ up to $60 \%$ ), Betula and Juniperus are the most important. Charcoal concen- tration is extremely low (less than 15,000 fragments $/ \mathrm{cm}^{3}$ ). Macrofossil remains of Betula and Larix show that birch and larch were involved in the afforestation. We infer that open vegetation with pioneer herbs was dominant at the base of the zone and Betula, Larix and Juniperus were locally present. Probably the high percentage of pine pollen is in part due to long-distance transport as very few pine macrofossils were found. A similar vegetation type during the Late glacial has also been described for several sites in the southern Alps (Bertoldi 1968; Schneider and Tobolski 1985; Wick 1996a; Tinner et al. 1999).

\section{LPAZ Luc-B and MZ Luc-B and $-C(225-178 \mathrm{~cm})$, ca. 12100-4000 cal B.P. (10150-2050 B.C.)}

At the begning of this zone Quercus (deciduous), Ulmus, Tilia, Fraxinus excelsior t. and Corylus pollen values increase. Later the rise in Alnus glutinosa type (Alnus glutinosa and A. incana) was followed by an increase of Fagus and Carpinus pollen percentages, whereas percentage values of NAP decreased. Charcoal values were stable; only in one sample was a peak registered.

Palaeobotanical data suggest that at the beginning of this zone mixed oak forests were present on the hills near the lake, while alder occurred in wetter places. The local presence of this vegetation type is confirmed by macrofossil results such as Quercus (deciduous) and Alnus glutinosa remains. Our palaeovegetational records suggest that afterwards the mixed oak forests were partly replaced by Fagus and Carpinus ( $\sim 2600$ B.C.) The contemporaneous expansion of Fagus and Carpinus may be partly attributed to the low resolution of our pollen diagram. An impressive expansion in Najas flexilis seeds is recorded in the macrofossil diagram ( $\sim 3150$ B.C., MZ Luc-C). Today this annual and rather thermophilous aquatic plant lives in freshwater bodies up to three metres deep. The minimum germination temperature for successful growth lies around $19^{\circ} \mathrm{C}$ during the second half of June (Haas 1996). Although this species no longer occurs in northern Italy (Pignatti 1982), a few $\mathrm{Na}$ jas flexilis seeds were previously found at Lago di Ganna (Schneider and Tobolski 1985) and dated to the Boreal chronozone (ca. 9,000-8,000 B.P., Mangerud et al. 1974). The occurrence of seeds in our record could be related to oligotrophic to slightly mesotrophic water conditions (Haas 1996).

Table 3 AMS-radiocarbon dates from Lago Lucone (LUC-1) ${ }^{\mathrm{a}}$

\begin{tabular}{lllllll}
\hline $\begin{array}{l}\text { Lab- } \\
\text { number }\end{array}$ & $\begin{array}{l}\text { Depth } \\
(\mathrm{cm})\end{array}$ & Material dated & Years ${ }^{14} \mathrm{C}$ в.P & $\delta^{13} \mathrm{C}(\%$ o $)$ & Age cal в.P. $(2 \sigma)$ & Mean calibrated date \\
\hline Poz-3201 & $149-150$ & Periderm and Quercus sp. bud scale & $2545 \pm 35$ & -28.4 & $2750-2490$ & 2735 cal в.P., 785 в.C. \\
Poz-3111 & 176 & periderm and Quercus sp. base of acorn & $3650 \pm 35$ & -23.6 & $4090-3865$ & 3950 cal в.P., 2000 в.C. \\
Poz-3203 & $202-204$ & Quercus sp. bud scale, Alnus glutinos seed & $4485 \pm 35$ & -27.4 & $5300-4975$ & 5145 cal в.P., 3195 в.C. \\
Poz-3202 & 237 & Terrestrial seed & $13,280 \pm 70$ & -26.7 & $16440-14970$ & 15,960 cal в.P., 14010 в.C. \\
\hline
\end{tabular}

${ }^{a}$ Calibration was carried out with CALIB rev 4.3 using the IntCal98 database (Stuiver et al. 1998) 
Table 4 Estimation of the percentage of open land in the RSA (1000 m radius area around the lake). Deforestation index is based on the estimated percentage of open land: $1.0-30 \% ; 2.30-60 \%$; $3.60-80 \%, 4.80-100 \%$
Table 5 Selection of non-arboreal pollen types used as anthropogenic indicators. The catagory of land used was assigned to the pollen types following Behre (1981), Birks (1990), Gaillard et al.

(1992), Ellenberg et al. (1992) and Pignatti (1982). Number of + indicates the number of authors. Pollen types in bold were chosen as indicators of a land use catogory (grey fill).

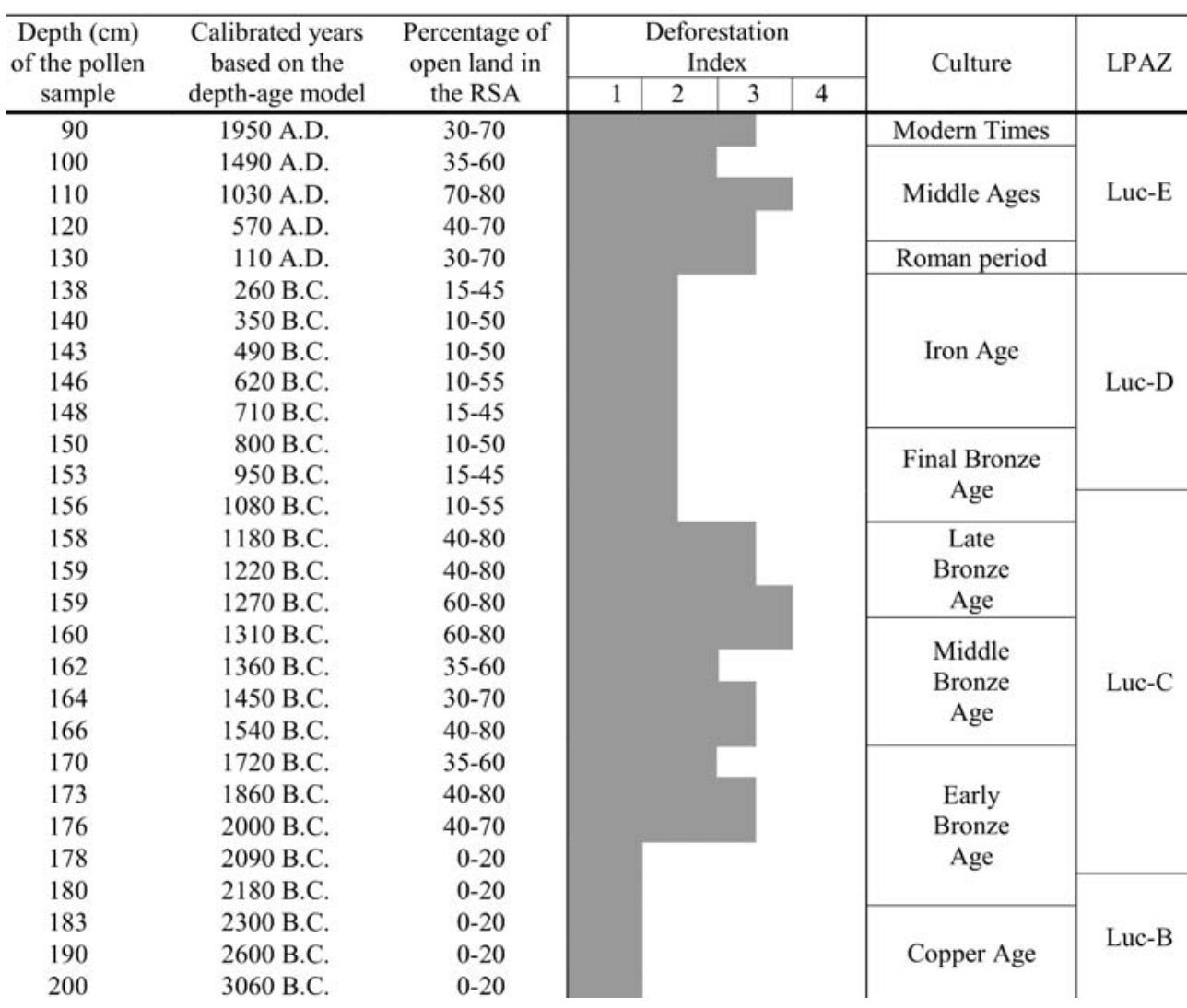

\begin{tabular}{|c|c|c|c|c|c|c|c|c|}
\hline \multirow{2}{*}{$\begin{array}{c}\text { POLLEN } \\
\text { TYPE }\end{array}$} & \multicolumn{8}{|c|}{ LAND USE CATEGORIES AND ECOLOGY } \\
\hline & Field & $\begin{array}{c}\text { Fallow land } \\
\text { ruderal } \\
\text { communities }\end{array}$ & Pastures & Mowing & $\begin{array}{c}\text { Grazing } \\
\text { and wet } \\
\text { meadows }\end{array}$ & $\begin{array}{c}\text { Wet } \\
\text { meadow }\end{array}$ & $\begin{array}{c}\text { Dry } \\
\text { meadow }\end{array}$ & $\begin{array}{c}\text { Natural } \\
\text { communities } \\
\text { in Garda area }\end{array}$ \\
\hline Apiaceae & & & & + & & + & & + \\
\hline Artemisia & & + & + & & & + & & rare \\
\hline Cannabis sativa & + & & & & & & & absent \\
\hline Centaurea nigra $\mathrm{t}$. & & & + & & & & & + \\
\hline Centranthus & & + & & & & & & absent \\
\hline Cerealia & ++ & & & & & & & rare \\
\hline Chenopodiaceae & & ++ & & & & & & rare \\
\hline Cirsium & & + & & & + & & & + \\
\hline Cyperaceae & & & & & + & & & + \\
\hline Filipendula & & & & + & & ++ & + & + \\
\hline Fritillaria $\mathrm{t}$. & & & + & & & + & + & rare \\
\hline Helianthemum/Cistus & & & + & + & & & + & rare \\
\hline Humulus lupus & & & & & & + & & + \\
\hline Linum austriacum t. & & & & & & & ++ & + \\
\hline Menthat. & & + & & & & ++ & & + \\
\hline Orlaya grandiflora & & + & & & & & & absent \\
\hline Plantago lanceolata t. & & + & ++ & + & & & & rare \\
\hline Plantago media & & & + & & & & ++ & + \\
\hline Poaceae & & + & + & & & + & & + \\
\hline Polygonum bistorta t. & & & + & & & & & rare \\
\hline Potentilla $\mathrm{t}$. & & & + & & & + & + & + \\
\hline Ranunculus acris t. & & & & & ++ & & & + \\
\hline Rhinanthus & & & ++ & + & & & & rare \\
\hline Rubiaceae & & + & ++ & & & & & + \\
\hline $\begin{array}{l}\text { Rumex acetosa t. / } \\
\text { R. acetosella }\end{array}$ & & + & +++ & & & + & & rare \\
\hline Rumex alpinus & & + & & & & + & & + \\
\hline Sanguisorba minor & & & & & & & ++ & + \\
\hline Scabiosa & & + & & & & & ++ & + \\
\hline Secale & ++ & & & & & & & absent \\
\hline Thalictrum & & & & & & + & + & + \\
\hline Trifolium repens t. & & ++ & + & & & & & rare \\
\hline Urtica & & ++ & & + & & & & rare \\
\hline
\end{tabular}




\section{LAGO LUCONE-LUC 1}

Plant macrofossil concentration diagram

Analysis: V.Valsecchi

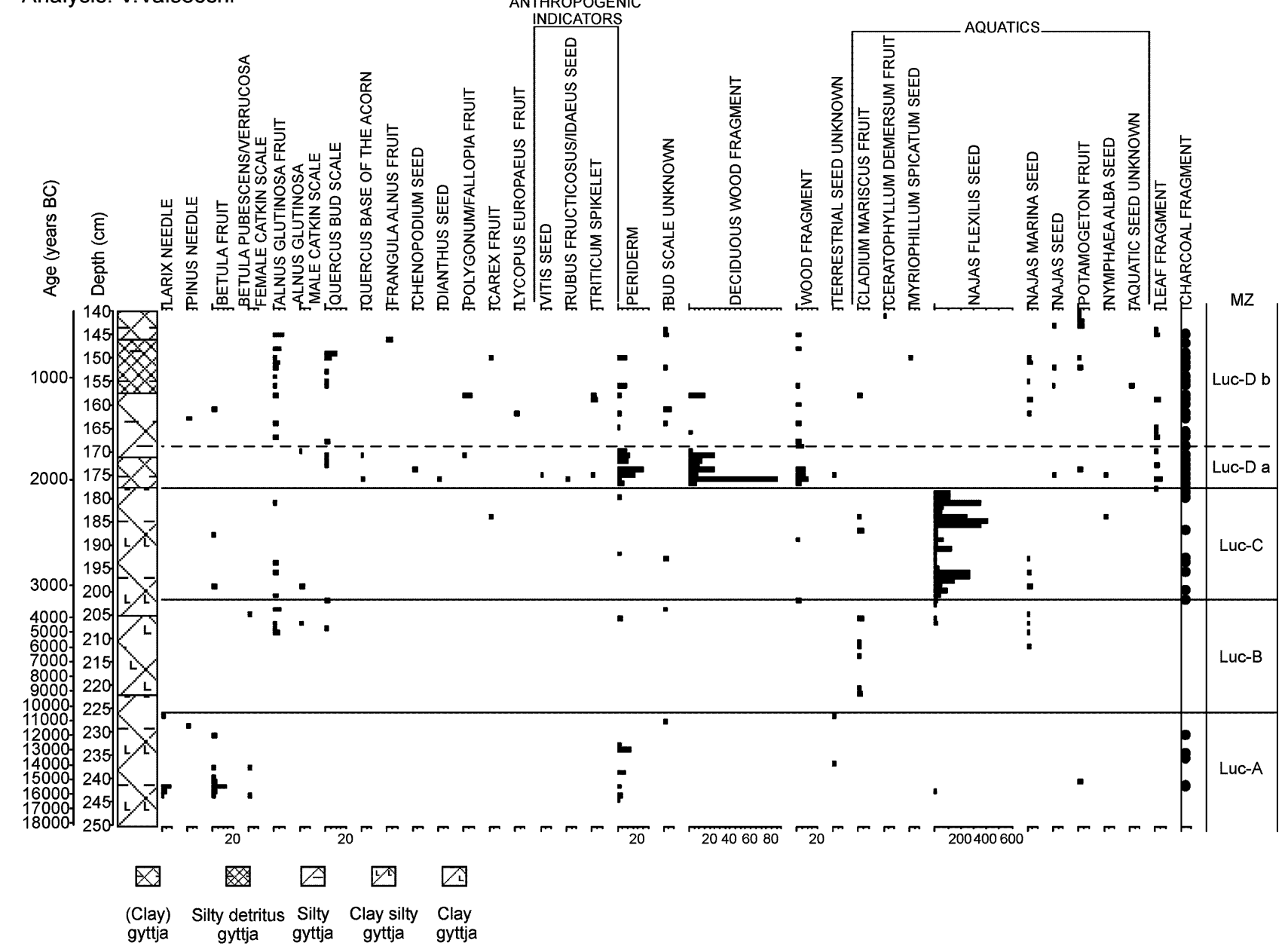

Fig. 4 Plant-macrofossil concentration diagram for Lago Lucone. Values refer to a sediment volume of $50 \mathrm{~cm}^{3}$

\section{LPAZ Luc-C and MZ Luc-D (178-157 cm), ca. 4000-3100 cal B.P. (2050-1150 B.c.)}

The beginning of this zone is characterised by high values of NAP (up to $45 \%$ ). The main taxa involved are Mentha t., Centaurea nigra t., Ranunculus acris $\mathrm{t}$. and Potentilla $\mathrm{t}$., as well as several pollen types indicative of human activities (Cerealia, Urtica, Orlaya grandiflora, Rumex acetosa t./acetosella, Trifolium repens t. and scattered Secale). An increase of Pteridium aquilinum spores is also visible; this species is often connected to fire events (Tinner et al. 1999). A more intense occurrence of fire is also indicated by a five-fold increase in the microscopic charcoal concentration (Fig. 5). In the plant-macrofossil record, wood and charcoal fragments reach high quantities (zone MZ Luc-Da 178-169 cm) and Triticum spikelet bases as well as Vitis and Rubus seeds were found. We infer that a reduced oak forest was still present on the surrounding hills, while alder grew near the lake shore. Forest reduction was probably caused by human activity as also suggested by the presence of several anthropogenic indicators and the enormous increase in microscopic and macroscopic charcoal concentration. These latter were probably related to local fire events. Moreover, the disappearance of Najas flexilis in the sediment of Lago Lucone at the beginning of this zone ( $\sim 2000$ cal B.P.) could be related to eutrophication that occurred as a consequence of human settlement.

\section{LPAZ Luc-D and MZ Luc-D (157-135 cm), ca. 1150 - ca. 350 B.c.}

This zone is characterised by a decrease in upland herb pollen values (up to 10\%). At the beginning of this zone, pollen percentages of Carpinus, Alnus glutinosa t., Ulmus, Fraxinus excelsior t. and Corylus increase, whereas microscopic charcoal concentration values are lower than in the previous zone. Only one peak was detected which was followed by a maximum in Pteridium aquilinum. Afforestation was mainly by Carpinus, however the macrofossil record suggests that Alnus glutinosa expanded locally around the lake. 
Fig. 5 Percentage pollen diagram of selected taxa for Lago Lucone

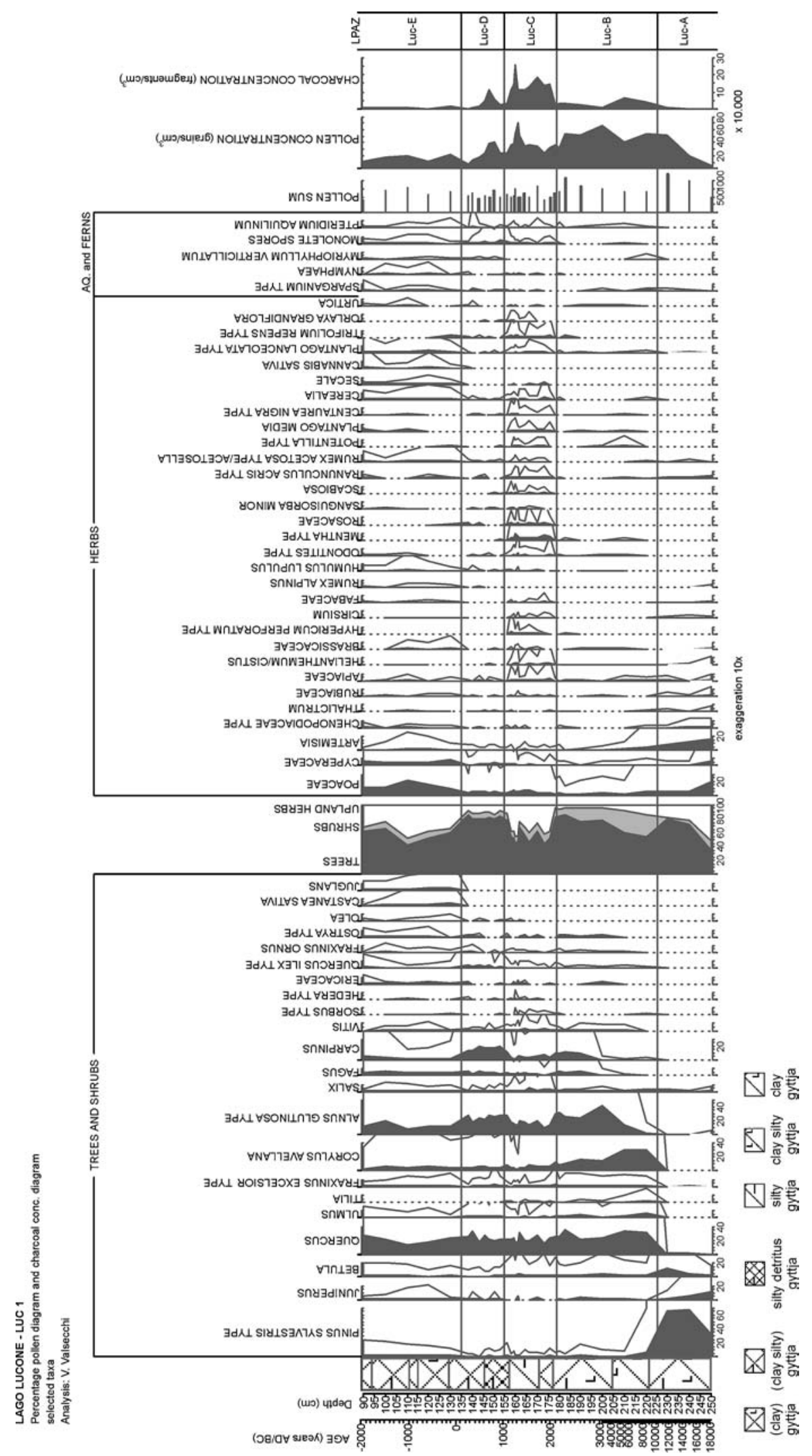




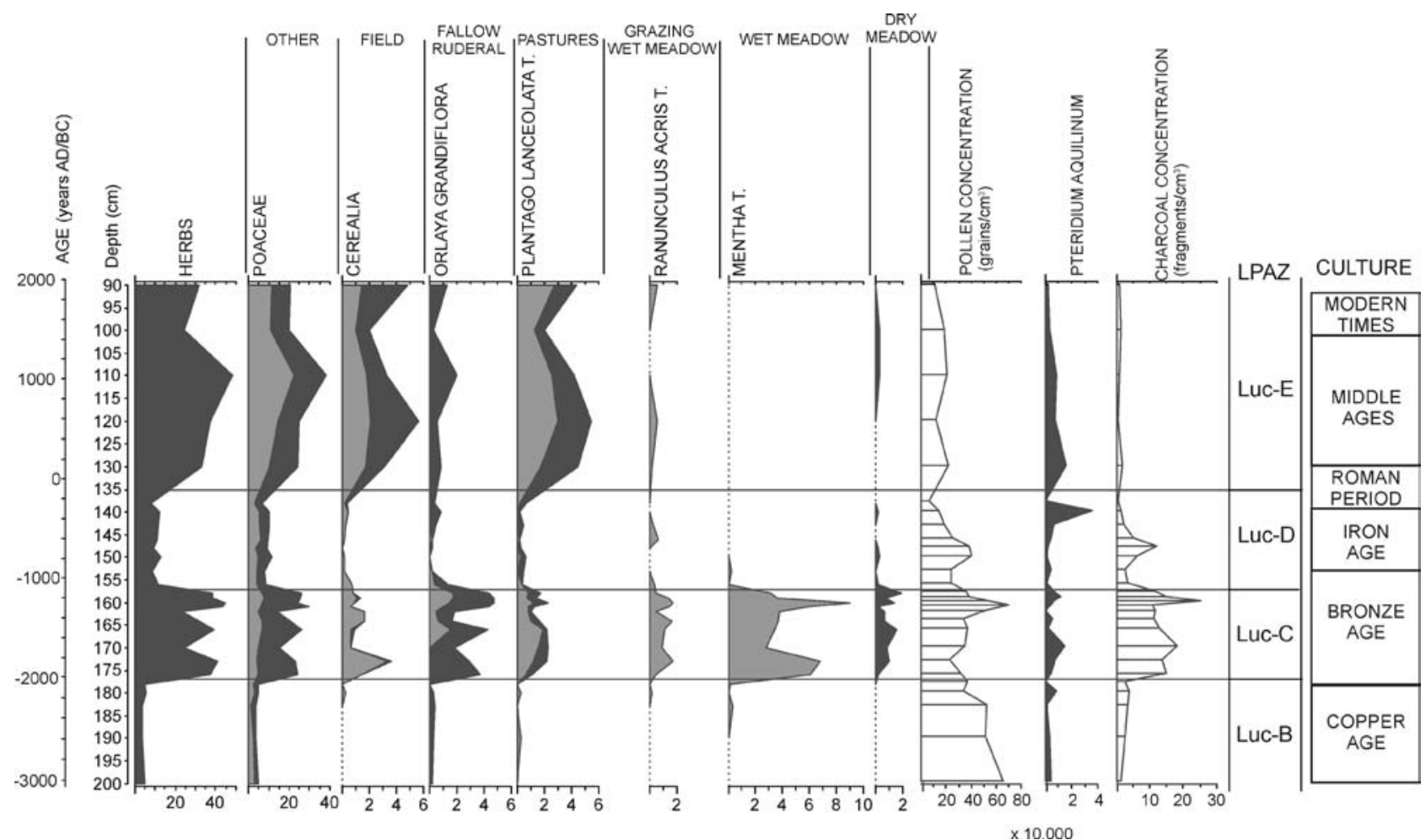

Fig. 6 Percentage pollen diagram of selected non-arboreal taxa. Pollen types are divided by the category of use and ecology. Black curves indicate the total pollen percentage of each category (e.g.

field), grey curves show pollen percentages of the indicated pollen type (e.g. Cerealia)

\section{LPAZ Luc-E (135-90 cm), ca. 350 B.C.-A.D. 1950?}

In this zone Castanea and Juglans pollen appear together with Cannabis sativa and Secale. At the same time Carpinus, Quercus and Alnus glutinosa t. decrease. These changes reflect strong human impact, i.e. agricultural and silvicultural activities related to the Roman period.

An attempt to quantify the landscape openness

Different periods of intensified human impact were detected in our study and were assigned according to age to the Copper Age, Bronze Age, Roman period, Middle Ages or Modern Times (Table 4). During the Copper and Early Bronze Age (ca. 3000-2200 B.C.) the forest was rather dense with estimated open land of $\sim 0-20 \%$ of the RSA ( $\sim 1000 \mathrm{~m}$ around the palaeo-lake). Subsequently, around 2000 B.C., the landscape was opened as evidenced by a sudden increase in the estimated open land cover percentage (reaching $80 \%$ of the RSA). This reduction in the forest cover, which lasted until $\sim 1100$ B.C., could be attributed to human forest clearances related to the establishment of the pile dwellings (Table 4). However, slightly lower values of open land cover percentages around 1700 and 1350 в.C. suggest that a reforestation of minor importance could have occurred. Then, during the Final Bronze and Iron Age the open land cover in the RSA was ca. $15-50 \%$ of the total area. Hence, a clear re-expansion phase of the forest is inferred, which ended during the Roman period and Middle Ages, when ca. $70-80 \%$ of the area was deforested.

Changes in the use of open land

In order to characterise the land use around the archaeological site at Lago di Lucone, NAP-types indicative of human impact were divided into different categories (Table 5).

During the Copper Age, NAP percentages were very low and among the herbs Poaceae pollen was dominant (Fig. 6). A change towards more intensive land use occurred during the Early Bronze Age (ca. 2000 в.C., LPAZ Luc-C), when the first unambiguous evidence of cultivation is recorded (Cerealia ca. 1.5\%). Plants indicative of grazing (e.g. Plantago lanceolata t. and Polygonum bistorta t.), fallow land and ruderal communities (Urtica, Chenopodiaceae), as well as wet meadows (e.g. Mentha t.) were common or very common. This vegetational pattern suggests that starting from ca. 2000 B.c. the landscape was exposed to more intense human management than before. The influence of land-use is also indicated by the microscopic charcoal concentration record. Subsequently, during the Late-Final Bronze Age (ca. 1100 B.c.), a reforestation phase is evidenced by a lowering in the NAP percentages. Poaceae were dominant, whereas plants indicative of human impact (e.g. Plantago lanceolata t., Cerealia etc.) were less important but still present. A similar pattern is also characteristic 
of the Iron Age, whereas further intense impact on vegetation occurred during the Roman period (LPAZ Luc-E; Fig. 6). Evidence of grazing, ruderal communities, and cultivation of cereals and Cannabis sativa increased (Fig. 5). This tendency continued during the Middle Ages and Modern Times, when Poaceae as well as Plantago lanceolata t. reached their highest values.

\section{Discussion}

Human impact on vegetation during the Bronze Age

Pile-dwelling settlements in wet areas were characteristic of the Early-Middle Bronze Age in northern Italy (Cremaschi 1991-1992). During this period intensive agriculture is attested by several pieces of archaeological evidence (e.g. finding of ploughs and sickles; Perini 1982). Besides cultivation, animal husbandry was also important (Cremaschi 1991-1992).

At Lago Lucone, land-use changes by prehistoric populations are evidenced by the pollen, plant macrofossil and microscopic charcoal records (Figs. 4 and 5). A clearing phase in the area around the lake occurred between $\sim 2000$ and $\sim 1100$ B.C. (Table 4). However, small oscillations in the NAP pollen percentage can be seen and hypothetically these could be attributed to reforestation phases $(\sim 1700$ and 1350 B.C.) due to temporary abandonment of the settlement. This explanation seems unlikely, since some of the important anthropogenic indicators did not decrease or disappear (e.g. Plantago lanceolata t., Cerealia). Synchronously with the clearing phase, pollen values of several anthropogenic indicators increased (e.g. Cerealia, Orlaya grandiflora, Trifolium repens type; Fig. 6). Moreover, a large increase of microscopic charcoal fragments occurred since $\sim 2000$ в.C. (Fig. 5). Palynological richness $E\left(T_{n}\right)$ values show a sharp increase (Fig. 7D), either due to a change towards a more varied landscape (increasing mosaic structure) or due to an increase in floristic richness (Birks and Line 1992). In the plant macrofossil record of Lago Lucone spikelet bases of Triticum were found (Fig. 4) as well as remains of edible wild plants (e.g. bases of Quercus acorns, Rubus and Vitis seeds). Morphological features of Vitis seeds which were found during archaeological excavations carried out in area A at Lago Lucone (Fig. 2) were attributed to wild Vitis vinifera; however an early phase of grape cultivation was not excluded (Di Vora and Castelletti 1995).

Our records suggest a continuous presence of human activity for a long period (e.g. $\sim 900$ years) at Lago Lucone. The persistence of the settlement is attested by the almost constant occurrence of pile dwellings during the Early and Middle Bronze Age ( 2000-1300 B.C.; Fig. 7) and by lithic and bronze assemblages (Guerreschi 1980-1981; Bocchio 1985-1988). However, a slightly longer duration $(\sim 200$ years) of human influences at Lago Lucone is inferred from the palaeobotanical records and could be explained by a delay in afforestation, by the presence of settlements in areas not suitable for the conservation of any archaeological remains (e.g. on the surrounding hills) or by the exploitation of the area by groups coming from nearby settlements.

To conclude, the Lago Lucone record documents a strong influence of Bronze Age societies on the environment. The mixed oak forest was largely destroyed and the cleared areas used for cultivation and pastures, while the timber was probably employed in the building of settlements and manufacture of implements. Drastic changes in landscape vegetation during the Bronze Age were detected not only at our site but also in the Po Plain and in the northern and central Apennines (Oldfield et al. 2003), in Central Italy (Lago di Mezzano-Sadori et al. 2004) and north of the Alps (Gobet et al. 2003; Tinner et al. 2003).

Comparison between sites with respect to inferred human impact on vegetation

In order to compare the degree of human impact on vegetation, ten sites were chosen in which the Early-Middle Bronze Age (ca. 2200-1300 B.c.) had been studied by means of pollen analysis (Fig. 1A). These sites were classified as on-site or off-site records (Table 6). Five of the sites are located in areas where evidence of settlements is absent or remote from the site. We refer to these as off-site records-Lago di Origlio (Tinner et al. 1999), Lago di Muzzano (Gobet et al. 2000), Lago di Ganna (Schneider and Tobolski 1985), Lago di Annone (Wick 1996b), and Lago di Segrino (Gobet et al. 2000). The Terramara Santa Rosa di Poviglio (Ravazzi et al. 2004) and Tabina di Magreta (Bertolani Marchetti et al. 1989) records are considered as on-site records because the samples were from within archaeological excavations. These two records are located in the so called "Terramare", which are dry-pile settlements surrounded by ditches and ramparts and were present in the Po Plain during the Middle and Late Bronze Age (Bernabo' Brea et al. 1997). Due to its closeness to the Bronze Age settlement $(\sim 100 \mathrm{~m})$, Lago Lucone is also considered as an on-site record. Nevertheless, the Lago Lucone core is a lake sediment record within which archaeological layers were not detected. For a broader comparison we considered also two on-site records located in the forelands of the northern Alps: Twann (Ammann 1977) and Nussbaumersee (Haas and Hadorn 1998).

Off-site pollen records indicate the dominance of mixed oak forests in the lowlands of northern Italy during the Early-Middle Bronze Age (Schneider and Tobolski 1985; Wick 1996b; Tinner et al. 1999; Gobet et al. 2000). Among the ten sites huge differences in herb percentages exist; from $10-20 \%$ in off-site records, but with much higher values at Lago Lucone, Terramara di Poviglio and Tabina di Magreta. Surprisingly, low NAP percentages were documented in the Twann record. Among the herbs, Poaceae are dominant in off-site but not in all on-site records. At Lago Lucone and at Nussbaumersee anthropogenic indicators were more frequent. Cerealia pollen was present in almost all diagrams, but the highest values (ca. 5\%) were registered at the Terramara di Poviglio. Beside Cerealia 
Table 6 Non-arboreal pollen percentages from 2000 to 1300 B.C. (i.e. Early-Middle Bronze Age) for off-site records (Schneider and Tobolski 1985; Wick 1996b; Tinner et al. 1999; Gobet et al. 2000),

\begin{tabular}{|c|c|c|c|c|c|c|c|c|c|c|}
\hline \multirow{3}{*}{$\begin{array}{l}\text { Pollen type } \\
\text { HERBS }\end{array}$} & \multicolumn{5}{|c|}{ Off-site records } & \multicolumn{5}{|c|}{ On-site records } \\
\hline & Origlio & Muzzano & Ganna & Annone & Segrino & Lucone & Poviglio & Tabina di Magreta & Nussbaumersee $20 \%$ & Twann \\
\hline & $15 \%$ & $20 \%$ & $15 \%$ & $10 \%$ & $20 \%$ & $34 \%$ & $75 \%$ & $70 \%$ & & $5 \%$ \\
\hline Cerealia & $0.5 \%$ & rare & $<1 \%$ & $1 \%$ & $<1 \%$ & $2 \%$ & $5 \%$ & absent & $<1 \%$ & $2 \%$ \\
\hline Orlaya grandiflora & unclear & unclear & unclear & rare & unclear & $1 \%$ & rare & unclear & unclear & unclear \\
\hline Plantago lanceolata $\mathrm{t}$ & $1.5 \%$ & $1 \%$ & $<1 \%$ & $1 \%$ & $<1 \%$ & $1 \%$ & rare & unclear & $2 \%$ & $<1 \%$ \\
\hline $\begin{array}{l}\text { Rumex acetosa t./ } \\
\text { acetosella }\end{array}$ & $1 \%$ & $2 \%$ & absent & $1 \%$ & $2 \%$ & $<1 \%$ & rare & unclear & $<1 \%$ & rare \\
\hline Trifolium repens $\mathrm{t}$ & rare & rare & rare & rare & absent & $2 \%$ & absent & absent & rare & absent \\
\hline Urtica & rare & rare & $<1 \%$ & rare & rare & $0.5 \%$ & absent & absent & $<1 \%$ & absent \\
\hline
\end{tabular}

${ }^{a}$ Absent: pollen type not present during the time frame considered; Rare: pollen percentage curve not continuous; Unclear: pollen identification to genus or family level

pollen, common anthropogenic indicators at all sites were Plantago lanceolata t., Rumex acetosa t./acetosella and to a minor degree Urtica.

The presence of settlements is unequivocally registered in pollen records and stronger signals are obtained from on-site records. Occurrence of Cerealia pollen in almost all diagrams indicates that cultivation was widespread. How- and on-site records (Ammann 1977; Bertolani Marchetti et al. 1989; Haas and Hadorn 1998; Ravazzi et al. 2004) ${ }^{\mathrm{a}}$

.

\section{.}


Human population dynamics and climate changes are there any causal connections?

During the Bronze Age, agriculture, fishing, and animal husbandry permitted increasing population growth and more complex societies. At that time, human populations were highly dependent on natural energy sources and local nutrient production; harvest yields depended mainly on climate (Messerli et al. 2000). Several studies indicate that climatic changes were able to cause the collapse of prehistoric societies in the Near East, in South America, and in Europe (Weiss et al. 1993; van Geel et al. 1996; deMenocal 2001). Furthermore, north and south of the Alps cerealfield cultivation expanded pulse-wise during warm and dry climatic periods (Tinner et al. 2003).

It has been suggested that the reduction of archaeological records in the Garda area commenced at the end of the Middle Bronze Age (ca. 1300 B.C.). Although a possible explanation for the scant archaeological record from that time may be the transfer to higher settlements that are not preserved, as suggested by Grosse-Klee and Maise (1997) for Switzerland, the assessment of this problem is hampered by the lack of archaeological evidence. In contrast to the archaeological evidence, our palaeobotanical record suggests the persistence of human influence beyond the Middle Bronze Age; Cerealia and Plantago lanceolata $\mathrm{t}$. pollen were present continuously since $\sim 2200$ B.C. and spikelet bases of Triticum sp. occurred at $\sim 1100$ B.C. Despite this strong evidence of human influence, pile dwellings were not present on the lake shore at Lago Lucone according to our present archaeological knowledge.

Independent proxies for climatic and environmental changes might be considered for the discussion of potential links between climate and land-use intensities. We have chosen the following proxies: (i) climatic phases as summarised by Tinner et al. (2003) on the basis of Alpine dendroclimatic and Greenland oxygen isotope records and (ii) potential phases of solar-radiation changes as inferred from atmospheric $\Delta{ }^{14} \mathrm{C}$ record (Stuiver and Reimer 1993) (Fig. 7E and F).

A correspondence between short-term atmospheric ${ }^{14} \mathrm{C}$ variations (which is often used as a proxy for solar activity), Holocene glacier and tree-line fluctuations was observed in early studies (Denton and Karlen 1973). Later Magny (1993) detected a correspondence between atmospheric ${ }^{14} \mathrm{C}$ variations and lake-level changes. Short-term ${ }^{14} \mathrm{C}$ variations may result from variations in solar radiation which may induce climatic changes (van Geel et al. 1996; Beer et al. 1999; Björk et al. 2001; Bond et al. 2001; Blaauw et al. 2004). However, the relationship between climate and solar activity is not linear and is still a matter of discussion (Muscheler et al. 2004; Ponyavin 2004; Solanki et al. 2004). Moreover, without a comparison with other proxies for solar activity (e.g. ${ }^{10} \mathrm{Be}$ ) it is difficult to judge whether ${ }^{14} \mathrm{C}$ variations were influenced by factors other than solar activity (Stuiver et al. 1991). In order to analyse the correspondence between phases of human impact and climatic change at Lago Lucone, the presence of anthropogenic indicators in the pollen and plant macrofossil records as well as the palynological richness $E\left(T_{n}\right)$ were compared to proxies of climatic change (Fig. 7). According to the dendrochronological and archaeological records, the settlement phase at Lago Lucone (area D) started around 2160 B.C. (Early Bronze Age) (Martinelli 1996). For this time our pollen and plant-macrofossil records show the beginning of a marked human impact (Table 4, Fig. 7). In the Alps the climate was warm and dry (Tinner et al. 2003), and high solar activity can be inferred from low ${ }^{14} \mathrm{C}$ values. Thus, according to the available palaeoclimatic and palaeoenvironmental records the Early-Bronze Age occupation phase occurred during a favourable climatic period.

Our palaeobotanical record suggests that human impact on vegetation decreased or disappeared around 1100 B.C. (Fig. 7B and C). At that time, the Lago Lucone lake-level was probably decreasing, as suggested by the transition from fine detritus to detritus gyttja. Similarly, a general lowering of lake levels was described for the Swiss Plateau from 1150 to 800 B.C. (Magny 2004). This lowering of lake levels apparently coincided with the end of the warm phase on the Swiss Plateau and in the southern Alps, which is set at $\sim 1250$ B.C., whereas the beginning of the subsequent cold phase is set at $\sim 1000$ B.C. (Fig. 7; Tinner et al. 2003). In this context it is intriguing that atmospheric ${ }^{14} \mathrm{C}$ values would suggest a local minimum of solar activity around 1350 B.C. and a subsequent local increase between 1200 and 1000 B.C. Thus discrepancies exist between proxies for past solar radiation and Alpine palaeoclimatic series.

However, similar Bronze-Age settlement crises were also detected by off-site pollen records north and south of the Alps (Lago di Origlio, Muzzano, Soppensee and Lobsigensee) and in the Upper and Lower Engadin (Gobet et al. 2003; Tinner et al. 2003). Despite some connections with other palaeocultural series it is difficult to attribute changes in cultural activities at Lucone around 1100 B.c. exclusively to climatic change as was suggested for example for the periods 800-650 в.C. and 400-150 в.C. in Central Europe by Maise (1998). Cultural crises (e.g. wars), plagues or changes in spatial organisation as forcing factors for declining human impact in the area cannot be ruled out under the present state of knowledge. New, better-dated independent palaeoclimatic series from the region are urgently needed for better disentanglement of human and climatic forcing.

\section{Conclusions}

The Bronze Age in the Garda area was characterised by drastic changes in the vegetation, which were mainly caused by human impact. The mixed oak forest characteristic of the Early-Middle Holocene was cleared and replaced by open vegetation during the Bronze Age. Open lands were estimated to have been more than $60 \%$ of the total relevant pollen-source area between the Early and Middle Bronze Age (2200 and $\sim 1300$ в.с.). The pollen data suggest that open lands were used as cultivation fields, pastures and fallow land. However, when using the indicator-species approach it must be kept in mind that pollen types indicative 
of human impact can partly refer to natural environments or to several land-uses. The comparison between on-site records and off-site records with regard to their ability to detect local human impact by means of pollen indicated that drastic changes in the landscape are better recorded at sites close to settlements, whereas in off-site records human impact on vegetation is documented at lower amplitudes. Intensification of agriculture resulted in more crops, probably allowing the development of more complex societies from 2200 to 1300 B.C. Warm and dry climates during this period probably permitted higher agricultural production. At Lago Lucone, human pressure started to decrease around 1100 B.C., when Alpine climatic records indicate the end of a warm and dry phase ( $\sim 1250$ B.C.). Hence it might be suggested that the settlement at Lago Lucone was abandoned in response to a less warm and less dry climate. However, this conclusion seems in contrast with the lower lake level inferred from the lithology change at Lago Lucone and with an increase of solar activity $\sim 1200$ B.C. inferred from atmospheric ${ }^{14} \mathrm{C}$ values. Such contradictions should be re-addressed by new local palaeoclimatic series.

Acknowledgments We are grateful to M. Cremaschi for support and for improvements of the manuscript. We acknowledge A. Vezzola for permission for fieldwork. We further thank W. Tanner, C. Mangili, C. Ravazzi, and A. Sala for help with fieldwork, F. Oberli for laboratory work, P. von Ballmoos for informatics support, and C. Mangani, N. Martinelli, M. Baioni, and S. Manzella for discussions. Linguistic improvements of the manuscript by H.E. Wright Jr. are gratefully acknowledged. We are also indebted to the two referees, A. M. Mercuri and L. Sadori for valuable comments and corrections. Radiocarbon dates were funded by the Institute of Plant Sciences, University of Bern. The study was supported by a University of Bern fellowship for the first author (Bundes-und Austauschstipendium).

\section{References}

Ammann B (1977) Pollenanalytische Untersuchungen in den nachneolitischen Sedimenten der Ufersiedlung Twann. In: Ammann B, Furger AR, Joos M, Liese-Kleiber H (eds) Die neolithischen Ufersiedlungen von Twann. Der bronzezeitliche Einbaum und die nachneolithischen Sedimente, Staatlicher Lehrmittelverlag, Bern, pp 79-85

Baioni M, Bocchio G (2004) Distribuzione spaziale nel bacino del Lucone di Polpenazze (BS) tra Neolitico ed età del Bronzo. Recenti ricerce. Poster presented at Wetland Economies and Societies. Zürich (Switzerland), March 10-13

Beer J, Mende W, Stellmacher R (1999) The role of the sun in climate forcing. Quaternary Science Reviews 19:403-415

Behre K-E (1981) The interpretation of anthropogenic indicators in pollen diagrams. Pollen et Spores 23:225-245

Bernabo' Brea M, Cardarelli A, Cremaschi M (1997) Le Terramare, la piu' antica civiltà padana, Electa, Modena

Bertolani Marchetti D, Dallai D, Trevisan Grandi G (1989) Ricerche palinologiche sugli insediamenti preistorici e protostorici di Tabina di Magreta. In: Cardarelli A, Pulini I, Zanasi C (eds) Modena dalle origini all Anno Mille. Studi di archeologia e storia I. COPTIP, Industrie Grafiche, Modena, pp 229-233

Bertoldi R (1968) Ricerche pollinologiche sullo sviluppo della vegetazione tardiglaciale nella regione del Lago di Garda. Studi Trentini di Scienze Naturali, Sezione B 45:87-162

Birks HJB (1990) Indicator values of pollen types from post-6000 B.P. pollen assemblages from southern England and southern Sweden. Quaternary Studies in Poland 10:21-31
Birks HJB, Line JM (1992) The use of rarefaction analysis for estimating palynological richness from Quaternary pollenanalytical data. The Holocene 2:1-10

Björk S, Muscheler R, Kromer B, Andersen CS, Heinemeier J, Johnsen SJ, Conley D, Koc N, Spurk M, Veski S (2001) High-resolution analyses of an early Holocene climate event may imply decreased solar forcing as an important climate trigger. Geology 29:1107-1110

Blaauw M, van Geel B, van der Plicht J (2004) Solar forcing of climatic change during the mid-Holocene: indications from raised bogs in The Netherlands. The Holocene 14:35-44

Bocchio G (1985-1988) Saggio stratigrafico presso Lucone D. Polpenazze del Garda (BS). Annali del Museo Gavardo 16:15-43

Bond G, Kromer B, Beer J, Muscheler R, Evans MN, Showers W, Hoffmann S, Lotti-Bond R, Hajdas I, Bonani G (2001) Persistent solar influence on North Atlantic climate during the Holocene. Science 294:2130-2136

Broström A, Gaillard M-J, Ihse M, Odgaard B (1998) Pollenlandscape relationships in modern analogues of ancient cultural landscapes in southern Sweden-a first step towards quantification of vegetation openness in the past. Vegetation History and Archaeobotany 7:189-201

Castelletti L, Castiglioni E, Rottoli M (2001) L'agricoltura dell'Italia settentrionale dal Neolitico al Medioevo. In: Failla O, Forni G (eds) Le piante coltivate e la loro storia, Franco Angeli, Milano, pp 33-84

Cremaschi M (1991-1992) Economia ed uso del territorio: possibile crisi ambientale durante il Bronzo Recente. In: Cremaschi M, Aspes A, Barfield LH, Baroni C, Bernabo' Brea M, Bottazzi G, Castelletti L, Dall'Aglio PL, Fasani L, Maggi R, Martinelli N, Nisbet R, Rainieri G, Ravazzi C, Riedel A, Salzani L (eds) L'Età del Bronzo in Italia nei secoli dal XVI al XIV a.C. 1. L'Italia Settentrionale. Rassegna Archeologica 10, pp 180-182

Dalla Fior G (1932) Analisi polliniche di torbe e depositi lacustri della Venezia Tridentina. I contributo. Memorie del Museo di Storia Naturale della Venezia Tridentina 1:139-166

Dalla Fior G (1940) Analisi polliniche di torbe e depositi lacustri della Venezia Tridentina. V contributo. Memorie del Museo di Storia Naturale della Venezia Tridentina 5:121-176

Denton GH, Karlen W (1973) Holocene climatic variations-their pattern and possible cause. Quaternary Research 3:155205

Di Vora A, Castelletti L (1995) Indagine preliminare sull archeologia della vite (Vitis vinifera L.) in base ai caratteri diagnostici del vinacciolo. Rivista Archeologica dell Antica Provincia e Diocesi di Como 176:333-358

Ellenberg H, Weber HE, Düll R, Wirth V, Werner W, Paulissen D (1992) Zeigerwerte von Pflanzen in Mitteleuropa. Scripta Geobotanica 18, Goltze, Göttingen

Faegri K, Iversen J (1989) Where pollen is found. Organic deposits, origin and description. In: Faegri K, Kaland PE, Krzywinski K (eds) Textbook of pollen analysis, Wiley, Chichester, pp 39-52

Finsinger W (2001) Vegetation history and human impact at the Lago del Vei del Bouc (Argentera Massif, Maritime Alps). Quaternaire 12:223-233

Finsinger W, Tinner W (2005) Minimum count sums for charcoalconcentration estimates in pollen slides: reliability and potential errors. The Holocene 15:293-297

Gaillard M-J, Birks HJB, Emanuelsson U, Berglund BE (1992) Modern pollen/land-use relationships as an aid in the reconstruction of past land-uses and cultural landscapes: an example from south Sweden. Vegetation History and Archaeobotany 1:317

Gaillard M-J, Birks HJB, Ihse M, Runborg S (1998) Pollen/landscape calibrations based on modern pollen assemblages from surfacesediment samples and landscape mapping-a pilot study in South Sweden. In: Gaillard M-J, Berglund BE, Frenzel B, Huckriede $\mathrm{U}$ (eds) Quantification of land surfaces cleared of forest during the Holocene-Modern pollen/vegetation/landscape relationships as an aid to the interpretation of fossil pollen data, Paläoklimaforschung/Palaeoclimate Research 27. Fischer, Stuttgart, pp 31-52 
van Geel B, Buurman J, Waterbolk HT (1996) Archaeological and palaeoecological indicators of an abrupt climate change in The Netherlands and evidence for climatological teleconnections around 2650 BP. Journal of Quaternary Science 11:451-460

Gobet E, Tinner W, Hubschmid P, Jansen I, Wehrli M, Ammann B, Wick L (2000) Influence of human impact and bedrock differences on the vegetational history of the Insubrian Southern Alps. Vegetation History and Archaeobotany 9:175178

Gobet E, Tinner W, Hochuli PA, van Leeuwen JFN, Ammann B (2003) Middle to Late Holocene vegetation history of the Upper Engadine (Swiss Alps): the role of man and fire. Vegetation History and Archaeobotany 12:143-163

Grimm EC (1993) Tilia version 2.0 and Tilia*Graph 1.25, Illinois State Museum, Research and Collection Centre

Grosse-Klee E, Maise C (1997) Sonne, Vulkane und Seeufersiedlungen. Jahrbuch der Schweizerischen Gesellschaft für Ur- und Frühgeschichte 80:85-94

Guerreschi G (1980-1981) La stazione preistorica del Lago Lucone (Brescia) - Scavi 1965-1971. Annali del Museo Gavardo $14: 7-78$

Haas JN (1996) Pollen and plant macrofossil evidence of vegetation change at Wallisellen-Langachermoos (Switzerland) during the Mesolithic-Neolithic transition 8500 to 6500 years ago. Dissertationes Botanicae 267, Cramer, Berlin Stuttgart

Haas JN, Hadorn P (1998) Die Vegetations- und Kulturlandschaftsgeschichte des Seebachtals von der Mittelsteinzeit bis zum Frühmittelalter anhand von Pollenanalysen. In: Hasenfratz A, Schnyder M (eds) Das Seebachtal. Departement für Erziehung und Kultur des Kantones Thurgau, Thurgau, pp 221-255

Heiri O, Lotter AF, Lemcke G (2001) Loss on ignition as a method for estimating organic and carbonate content in sediments: reproducibility and comparability of results. Journal of Paleolimnology 25:101-110

Katz NJ, Katz SV, Kipiani MG (1965) Atlas and keys of fruits and seeds occurring in the Quaternary deposits of the USSR, Nauka, Moscow

Magny M (1993) Solar influences on Holocene climatic changes illustrated by correlations between past lake level fluctuations and the atmospheric ${ }^{14} \mathrm{C}$ record. Quaternary Research 40:1-9

Magny M (2004) Holocene climate variability as reflected by midEuropean lake-level fluctuations and its probable impact on prehistoric human settlements. Quaternary International 113:6579

Maise C (1998) Archäoklimatologie - Vom Einfluss nacheiszeitlicher Klimavariabilität in der Ur- und Frühgeschichte. Jahrbuch der Schweizerischen Gesellschaft für Ur- und Frühgeschichte 81:197-235

Mangerud J, Andersen ST, Berglund BE, Donner JJ (1974) Quaternary stratigraphy of Norden, a proposal for terminology and classification. Boreas 3:109-128

Marchesoni V (1958) Aspetti mediterranei lungo il margine meridionale delle Alpi con particolare riguardo al settore prealpino antistante al bacino atesino. Studi Trentini di Scienze Naturali $35: 47-69$

de Marinis RC (1999) Towards a Relative and Absolute Chronology of the Bronze Age in Northern Italy. Notizie Archeologiche Bergomensi 7:23-100

Martinelli N (1996) Datazioni dendrocronologiche per l'Età del Bronzo dell'area alpina. In: Ranndsborg K (ed) Absolute chronology: archaeological Europe 2500-500 BC, Acta Archeologica supplementa 67:315-326

deMenocal PB (2001) Cultural response to climate change during the Late Holocene. Science 292:667-673

Merkt J, Streif H (1970) Stechrohr-Bohrgeräte für limnische und marine Lockersedimente. Geologisches Jahrbuch, Beihefte 88:137-148

Messerli B, Grosjean M, Hofer T, Nunez L, Pfister C (2000) From nature-dominated to human-dominated environmental changes. Quaternary Science Reviews 19:459-479

Moore PD, Webb JA, Collinson ME (1991) Pollen Analysis, Blackwell Scientific Publications, London
Munsell (1954) Soil Color Charts, 1954 Edition. Munsell Color Company, Inc., Baltimore, USA

Muscheler R, Beer J, Vonmoos M (2004) Causes and timing of the $8200 \mathrm{yr}$ BP event inferred from the comparison of the GRIP ${ }^{10} \mathrm{Be}$ and tree ring $\Delta{ }^{14} \mathrm{C}$ record. Quaternary Science Reviews 23:2101-2111

Oldfield F, Asioli A, Accorsi CA, Mercuri AM, Juggins S, Langone L, Rolph T, Trincardi F, Wolff G, Gibbs Z, Vigliotti L, Frignani M, van der Post K, Branch N (2003) A high resolution late Holocene palaeo environmental record from the central Adriatic Sea. Quaternary Science Reviews 22:319-342

Perini R (1982) L'aratro del Lavagnone. Studi Trentini di Scienze Preistoriche 61

Pignatti S (1982) Flora d'Italia, Edagricole, Bologna

Pinna M (1977) Climatologia, UTET, Torino

Ponyavin DI (2004) Solar cycle signal in geomagnetic activity and climate. Solar Physics 224:465-471

Punt W et al. (1976-1996) The Northwest European Pollen Flora, vol 1 (1976); vol 2 (1980); vol 3 (1981); vol 4 (1984); vol 5 (1988); vol 6 (1991); vol 7 (1996). Elsevier, Amsterdam

Ravazzi C, Cremaschi M, Forlani L (2004) Studio archeopalinologico. Nuovi dati, analisi florisitca e sintassonomica della vegetazione nell'età del Bronzo. In: Bernabo' Brea M, Cremaschi M (eds) Il villaggio piccolo della Terramara di S. Rosa di Poviglio. Scavi 1987-1992, Origines, Firenze, pp 703 736

Reille M (1992-1998) Pollen et spores d'Europe et d'Afrique du nord. Supplement 1,2, Laboratoire de Botanique hostorique et Palynologie, Marseille

Sadori L, Giraudi C, Petitti P, Ramrath A (2004) Human impact at Lago di Mezzano (central Italy) during the Bronze Age: a multidisciplinary approach. Quaternary International 113:5-17

Schneider R, Tobolski K (1985) Lago di Ganna - Late-glacial and Holocene environments of a lake in the Southern Alps. Dissertationes Botanicae 87:220-271

Schoch WH, Pawlik B, Schweingruber FH (1988) Botanical macro-remains, Haupt, Bern Stuttgart

Solanki SK, Usoskin IG, Kromer B, Schussler M, Beer J (2004) Unusual activity of the Sun during recent decades compared to the previous 11,000 years. Nature 431:1084-1087

Stegagno G (1907) I laghi intermorenici dell'anfiteatro benacense. Laghi, stagni e paludi, Società Geografica Italiana, Roma

Stockmarr J (1971) Tablets with spores used in absolute pollen analysis. Pollen et Spores 13:614-621

Stuiver M, Reimer PJ (1993) Extended ${ }^{14} \mathrm{C}$ data base and revised CALIB $3.0^{14} \mathrm{C}$ age calibration program. Radiocarbon $35: 215-230$

Stuiver M, Braziunas TF, Becker B, Kromer B (1991) Climatic, solar, oceanic, and geomagnetic influences on late-glacial and Holocene atmospheric ${ }^{14} \mathrm{C} /{ }^{12} \mathrm{C}$ change. Quaternary Research 35:1-24

Stuiver M, Reimer PJ, Bard E, Beck JW, Burr GS, Hughen KA, Kromer B, McCormac FG, van der Plicht J, Spurk M (1998) INTCAL98 Radiocarbon Age Calibration, 24,000-0 cal BP. Radiocarbon 40:1041-1083

Sugita S (1994) Pollen representation of vegetation in Quaternary sediments: theory and method in patchy vegetation. Journal of Ecology 82:881-897

Sugita S, Gaillard M-J, Broström A (1999) Landscape openness and pollen records: a simulation approach. The Holocene 9:409_ 421

Tinner W, Hu FS (2003) Size parameters, size-class distribution and area-number relationship of microscopic charcoal: relevance for fire reconstruction. The Holocene 13:499-505

Tinner W, Hubschmid P, Wehrli M, Ammann B, Conedera M (1999) Long-term forest-fire ecology and dynamics in southern Switzerland. Journal of Ecology 87:273-289

Tinner W, Lotter AF, Ammann B, Conedera M, Hubschmid P, van Leeuwen JFN, Wehrli M (2003) Climatic change and contemporaneous land-use phases north and south of the Alps 2300 BC to 800 AD. Quaternary Science Reviews 22:14471460 
Ufficio idrografico e mareografico di Parma-Bacino del Po (19621991) Annali Idrologici, Istituto Poligrafico dello Stato, Roma

Venzo S (1957) Rilevamento geologico dell'anfiteatro morenico del Garda. Parte I: tratto occidentale Gardone-Desenzano. Con carta al 25,000. Memorie della Società Italiana di Scienze Naturali e del Museo Civico di Storia Naturale di Milano 12:79-140

Weiss H, Courty M-A, Wetterstrom W, Guichard F, Senior L, Meadow R, Curnow A (1993) The genesis and collapse of Third Millennium North Mesopotamiam civilization. Science 261:995-1004
Wick L (1996a) Late-glacial and early-Holocene palaeoenvironments in Brianza, N Italy. Il Quaternario 9:653660

Wick L (1996b) Spät- und postglaziale Vegetationsgeschichte in den Südalpen zwischen Comersee und Splügenpass, Unpublished Doctoral thesis, Universität Bern 